\title{
RESPOSTAS CORRELACIONADAS A SELEÇÃO DIVERGENTE PARA FLORESCIMENTO EM UM COMPOSTO DE MILHO (Zea mays L.)
}

PAULO JOSE DA SILVA LEITE

Orientador: Prof. Dr. JOÃO RUBENS ZINSLY

Dissertação apresentada à Escola Superior de Agricultura "Luiz de Queiroz", da Universidade de São Paulo, para obtenção do título de Mestre em Agronomia - Área de Concentração: Genética e Melhoramento de Plantas.

$P|R A C| C A B A$

Estado de São Paulo - Brasil

Novembro - 1985 
Aos meus pais,

à minha esposa

e aos meus filhos

DEDICO 


\section{AGRADECIMENTOS}

O autor manifesta os mais profundos agradecimentos a todos aqueles que direta ou indiretamente, contribuiram para a realização do presente trabalho, em especial para:

- Prof. Dr. João Rubens Zinsly, pela orientação dos tempos de estágio ao Curso de Mestrado;

- Prof. Dr. Isaias Olivio Geraldi, pelas suges tões na análise estatística do presente trabalho;

- Dr. Claudio Lopes de Souza Jr., pela colaboração e sugestões no desenvolvimento deste trabalho;

- Srta Erica Spruck, pelas inümeras cooperações na qualidade de secretária do I. Gen.;

- Dr. Wilhelmus P. M. Uitdewilligen, pelo estí mulo dado durante a elaboração deste trabalho;

- Srta Rosane Maria Werle, pela dedicação e cạ pricho na apresentação final deste trabalho. 
INDICE

página

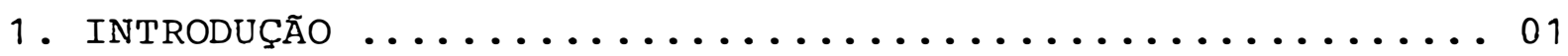

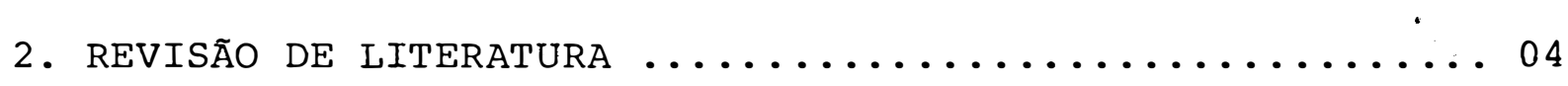

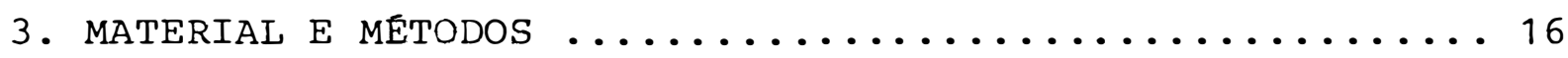

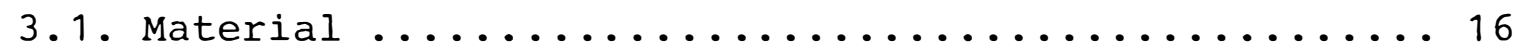

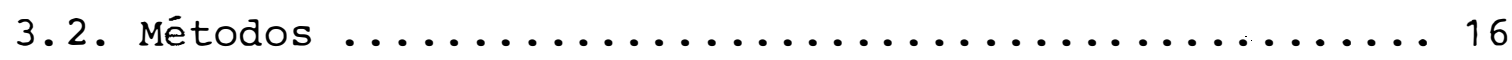

3.2.1. Obtenção do I ciclo de seleção .......... 17

3.2.2. Obtenção do II ciclo de seleção $\ldots \ldots \ldots \ldots 17$

3.2.3. Obtenção do III ciclo de seleção ......... 18

3.2.4. Avaliação experimental ............ 18

3.2.5. Análise estatística .............. 21

3.2.6. Estudo detalhado do progresso ......... 22

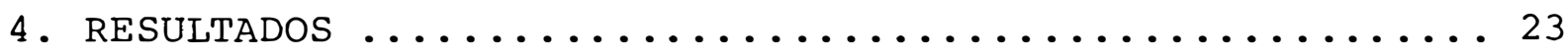

4.1. Resultados dos Ensaios de Competição .......... 23

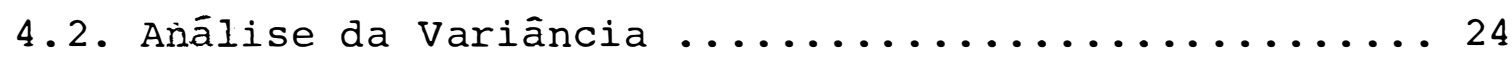

4.3. Estimativås dos Parâmetros ............... 27

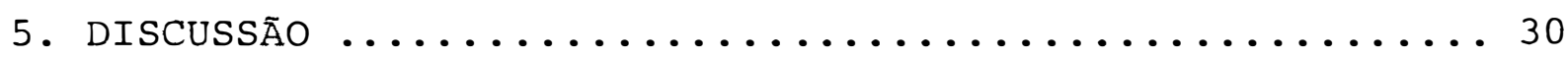

5.1. Seleção para Florescimento .............. 30

5.2. Respostas correlacionadas $\ldots \ldots \ldots \ldots \ldots \ldots \ldots \ldots \ldots$

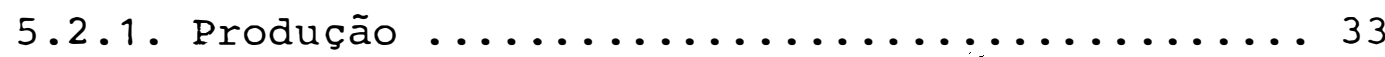

5.2.2. Umidade dos grãos na colheita ......... 34

5.2.3. Altura da planta e altura da espiga........35

5.2.4. Indice de espigas $\ldots \ldots \ldots \ldots \ldots \ldots \ldots \ldots$

5.3. Metodologia Empregada .................. 37 
6. CONCLUSOES .............................40

7. LITERATURA CITADA ...................... 41

8. TABELAS E GRÁFICO DE RESULTADOS .............. 46 
LISTA DE TABELAS E GRAFICO

página

Tabela 1 - Médias obtidas no ensaio em blocos ao acaso, 10 repetições. Estação Experimental de Anhumas. $1979 / 80 \ldots \ldots \ldots \ldots \ldots \ldots \ldots \ldots \ldots \ldots \ldots \ldots$

Tabela 2 - Médias obtidas no ensaio em blocos ao acaso, 8 repetições. Piracicaba. 1979/80..........4 48

Tabela 3 - Análise da variância e significância dos qua drados médios das características avaliadas em blocos ao acaso em 10 repetições. Estação Experimental de Anhumas. 1979/80 .........4 48

Tabela 4 - Análise da variância e significância dos qua drados médios das características avaliadas em blocos ao acaso com 8 repetições. Piraci-

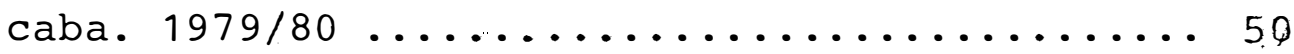

Tabela 5 - Estimativas dos parâmetros: média da população original (m), ganho por ciclo devidoá se leção para plantas precoces $\left(G_{p}\right)$ e, ganho por ciclo devido à seleção para plantas tardias $\left(G_{t}\right)$, para as diversas caracteristicas avaliadas em Anhumas. 1979/80.............. 51

Tabela 6 - Quadrados médios das estimativas dos parâmetros $G_{p}$ e $G_{t}$, da comparação $G_{p}$ "vs" $G_{t} e$, dos desvios do modelo adotado, para as características avaliadas em Anhumas. 1979/80...... 52 
Tabela 7 - Estimativas dos parâmetros: média da população original (m), ganho por ciclo devido à se leção para plantas precoces $\left(G_{p}\right)$ e, ganho por ciclo devido a seleção para plantas tardias $\left(G_{t}\right)$, para as diversas características avalia das em Piracicaba. 1979/80.............. 53

Tabela 8 - Quadrados médios das estimativas dos parâme$\operatorname{tros} G_{p}$ e $G_{t^{\prime}}$ da comparação $G_{p}$ "vs" $G_{t} e$, dos desvios do modelo adotado, para as caracterís ticas avaliadas em Piracicaba. 1979/80 ....... 54

Gráfico 1 - Regressão linear obtida pelo método dos quadrados minimos, para dias para florescimento feminino sobre ciclos de seleção para precoci dade (3) e plantas tardias (2), para cada 10cal avaliado. ..................... 55 
viii

\section{CURRICULUM VITAE}

Paulo José da Silva Leite, filho de Luiz.Gonzą ga da Silva Leite e Zelinda Chiozzini Leite, nasceu em 29 de julho de 1955, na cidade de Matão, Estado de São Paulo. Ingṛes sou na Escola Superior de Agricultura "Luiz de Queiroz", da Universidade de São Paulo, em 1975, onde graduou-se em Engenharia Agronômica no ano de 1978. Realizou estágio no Departamen to de Genética no período de setembro de 1975 a dezembro de 1978, na área de Melhoramento de Milho, sob orientação do Prof. Dr. João Rubens Zinsly, que também o orientou durante o curso de Pós-Graduação, onde ingressou em 1979, visando a obtenção do título de Mestre em Genética e Melhoramento de Plantas. Du rante o ano de 1980, foi professor da disciplina Citologia e Genética do curso de Agronomia, da Universidade de Taubaté. Em 1981, foi contratado pela Sociedade Agrícola Germinal Ltda. ,on de permanece, ocupando o cargo de Chefe da Seção de Pesquisa e Desenvolvimento de Sementes de milho para a Região Sul do Brasil. 


\section{RESPOSTAS CORRELACIONADAS À SELEÇÃO DIVERGENTE \\ PARA FLORESCIMENTO EM UM COMPOSTO DE MILHO \\ (Zea mays L.)}

PAULO JOSE DA SILVA LEITE

ORIENTADOR: Prof. Dr. João Rubens Zinsly

\section{RESUMO}

o presente trabalho teve por objetivo o estudo das respostas correlacionadas à seleção divergente para flores cimento, em diversos outros caracteres da planta de milho.

Para tanto, foi utilizado o composto de milho ESALQ-PB-1, sintetizado no Departamento de Genética da ESALQUSP, sobre o qual foram efetuados 3 ciclos de seleção para pre cocidade e 2 ciclos de seleção para plantas tardias, com base no florescimento feminino. Foi feita a seleção massal com crü zamentos duas a duas ("sib") entre as 5\% plantas mais precoces e as 5\% plantas mais tardias. Os 3 ciclos de seleção para pre cocidade e os 2 ciclos de seleção para plantas tardias, juntamente com a população original e uma testemunha, foram avaliadas em dois locais: na Estação Experimental de Anhumas e na área experimental no Departamento de Genética, ambos no município de Piracicaba-SP, no ano agrícola de 1979/80.

Verificou-se ganhos significativos na seleção 
para precocidade, com reduções no nümero de dias para o flores cimento feminino de 4,5 dias/ciclo na estimativa feita em Anhu mas e de 2,3 dias/ciclo na estimativa feita com base nos resul tados de Piracicaba. A seleção para plantas tardias não foi e fetiva, resultando em ganhos não significativos nos dois locais avaliados.

Para os outros caracteres avaliados: produção, umidade dos grãos na colheita, altura da planta, altura da espiga e indice de espigas, não se verificou respostas correlacio nadas significativas. Observou-se uma tendência de os materiais mais precoces terem melhor produtividade nas condições ad versas ocorridas em Anhumas. Foi detectada diferença significativa entre os ciclos de seleção para altura da planta e altú ra da espiga. As alterações desse caráter ocorreram de maneira errática ao longo dos ciclos, o que resultou em ganhos não significativos. 


\title{
CORRELATED RESPONSES TO FLOWERING DIVERGENT SELECTION \\ ON A MAIZE COMPOSITE (Zea mays L.)
}

\author{
PAULO JOSE DA SILVA LEITE \\ Adviser: Prof.Dr. João Rubens Zinsly
}

\section{SUMMARY}

The objective of the study was to observe the correlated responses of several maize characteristics to diver gent selection for flowering.

The composite ESALQ-PB-1, sintetised on the ESALQ-USP Genetics Department was used. Three selection cycles for earliness and two for late silking were produced using mass selection and full sibbing among the 5\% earliest plants for early flowering and 5\% latest flowering for the opposite selec tion.

Three cycles for earliness and 2 for late flowering were obtained which added to the original composite and a commercial hybrid were evaluated at two locations: Anhu mas Experimental Station and Genetics Department experimental site on the 79/80 agricultural season.

Significant gains for earliness were observed averaging 4,5 days per cycle at Anhumas and 2,3 days per cycle for the trial at Piracicaba. Selection for later plants resul 
ted in non significant gains at the two locations.

No significant correlated responses were obser ved for yield, grain moisture at harvest, plant and ear height and ears per plant. There was a tendency for the earlier genotypes to have higher yields under the unfavourable environment of Anhumas. There were significant differences for plant and ear height among cycles of selection without stability over cycles resulting in no significance for the gains. 


\section{INTRODUÇÃO}

Diversas situações, principalmente associadas a condições climáticas, podem fazer da duração do ciclo fator de fundamental importância na escolha da variedade ou híbrido de milho a ser cultivado, visando maximizar as possibilidades de colheita.

Assim, em regiões de clima quente, com boa regularidade na distribuição de chuvas, se esperaria melhores co lheitas com milhos, de ciclo tardio que aproveitassem melhor to da radiação luminosa e água disponíveis. Para outras regiões, como por exemplo, os cerrados brasileiros ou mesmo os Estados do sul do Brasil, onde tradicionalmente ocorre um periodo de se ca durante o ciclo agrícola (o chamado veranico), deve ser dada preferência àquelas variedades ou hỉbridosque floresçam fora desse período, uma vez que essa é a fase em que a planta requer maior volume de água disponível. Nesse caso, pode-se conjugar ciclos com épocas de plantio, quando se tem alternativas para estas. 
Usualmente, se considera os milhos precoces me nos produtivos que os tardios. Entretanto, diversos trabalhos. encontrados na literatura, tem mostrado que, em condições adversas, milhos de ciclo precoce apresentam um comportamento me Ihor em termos de produtividade ou mesmo de acamamento e quebra mento de colmo, que os tardios (TROYER(1967); STANLEY e RHOADES (1975) e De LOUGHERY e CROOKSTON(1979)).

De qualquer maneira, outros fatores que não os climáticos, podem influir na escolha. A utilização mais racio nal do solo, com dois ciclos de cultivo por ano e dentro de um esquema de rotação de culturas, praticado já em muitas regiões de agricultura mais desenvolvida no Brasil, exige comprimentos de ciclo adequades para todas as culturas envolvidas.

Dessa forma, o termo precoce ou tardio, pode se referir tanto ao número de dias necessários ao florescimento, quanto ao número de dias necessārios para que os grãos atinjam uma umidade que permita a colheita, já que esses caracteres tem uma associação bastante forte. O ciclo também está associado ao porte de planta. Assim, os milhos precoces tendem a ter um porte mais reduzido em relação aos tardios. Um exemplo extremo, pode ser visto comparando-se os milhos tropicais, normalmente tardios e de grande porte, com os originários de climas temperados, como os do Corn Belt (E.U.A.), precoces e de porte reduzido.

Uma maneira de se conseguir milhos precoces com 
boa adaptação as condições brasileiras, seria explorar a varia bilidade existente para ciclos nos milhos tropicais, através da seleção.

o objetivo deste trabalho é estudar as alteraçoes ocorridas em diversos caracteres da planta, devido à sele ção divergente para florescimento, isto é, para precocidade e para plantas tardias, aplicada em um composto de milho, formado pela recombinação de populações tropicais. 


\section{REVISÃO DE LITERATURA}

O conhecimento da herança ou da base genética de um carater, é importante na elaboração de programas de sele ção para o mesmo.

Visando conhecer a herança das caracteristicas florescimento feminino e altura da planta em milho, YANG(1949) analisou cruzamentos envolvendo duas linhagens endógamas de cí clos e alturas de plantas semelhantes, avaliando as gerações $F_{\text {¡ }}$ $\mathrm{F}_{2}, \mathrm{RC}_{1}$ e $\mathrm{RC}_{2}$. Os resultados mostraram que cada linhagem possuia diferentes genes para elongação do colmo e ciclo da planta, já que houve um efeito diferenciado no $F_{1}$. Por outro lado, o nūmero de genes em que essas duas linhagens diferem para os caracteres é pequeno: provavelmente 2 pares de genes contro lam a época do florescimento e 3 pares controlam a altura da planta, havendo indicações de efeitos de dominância.

Já SETTY(1975), apresentou dados que permitem a conclusão de que o número de dias para o florescimento femi- 
nino em milho é controlado por 3 pares de genes.

Num trabalho bastante amplo, GARDNER et alii (1953), estudaram duas populações $\mathrm{F}_{2}$ oriundas de cruzamentos de linhagens de milho e os respectivos parentais. Plantas $\mathrm{F}_{2}$ tomadas ao acaso, foram retrocruzadas com cada uma das linhagens parentais para produzir pares de progênies de retrocruzamentos para cada planta. O grau médio de dominância para dias para florescimento para a primeira população foi 0,82 e para a segunda 0,74 . As estimativas das variâncias genéticas dominante e aditiva para essa característica, mostrou uma predominância acentuada de efeitos gênicos aditivos nas duas populações estú dadas.

DANIEL(1972) fez uma análise para o carater pre cocidade em milho, em um cruzamento dialélico envolvendo 11 li nhagens que diferiam quanto a esse carater, encontrando a presença de efeitos gênicos aditivos e a ocorrência de 4 loci com dominância parcial'no controle da precocidade em milho. A heterose (para precocidade) dos cruzamentos foi maior quando a di versidade entre os pais era pequena, enquanto que quando os pais mostravam maior diferença, o comportamento do $\mathrm{F}_{1}$ era intermediário.

Conclusões semelhantes às relatadas até aqui fọ ram obtidas em outro trabalho desse mesmo autor, DANIEL(1973), que constatou ainda a ausência de epistase no controle desse carater. 
Também PATIL (1977) observou que o número de dias para florescimento feminino e número de dias para a maturação fisiológica são controlados por efeitos genéticos aditivos.

A grande divergência entre alguns dos autores citados está no número de genes que estariam no controledo flo rescimento feminino. DANIEL et alii(1974) concluíram que o nú mero minimo de alelos envolvidos é de 2 a 3 . Esses autores tam bém fizeram estimativas das variâncias devidas à capacidade ge ral de combinação e à capacidade específica de combinação para diversos caracteres. Para florescimento feminino, a variân cia devido à capacidade geral de combinação foi maior que a de vida à capacidade específica de combinação.

Pelos resultados da literatura observados até aquỉ, e de se esperar ganhos significativos na seleção para o carater florescimento feminino em populações de milho, dada a base genētica des'se carater.

SHEHATA et alii(1976) apresentam uma análise pa ra ó numero de dias até $50 \%$ do florescimento feminino e até a maturação fisiológica dos grãos, de um ensaio de avaliação de cruzamentos dialélicos feitos com 10 populações de mi.lho de diversas origens. Para ambos os caracteres a capacidade geralde combinação foi cerca de 10 vezes maior que a capacidade especí fica de combinação, o que indica que a seleção para precocidade pode ser bastante efetiva para essas populações avaliadas. 
Considerando-se que uma planta é um sistema fẹ chado, fisiológicamente equilibrado, é certo que a alterasão de uma característica, quer seja por seleção artificial ou natural, deverá provocar alterações em outras características para que o equilíbrio seja mantido.

PATERNIANI e ZINSLY(1965) relatam o resultado de três ciclos de seleção para aumento de produção na população Dente Paulista, onde se nota que ao mesmo tempo em que se obteve um substancial aumento na produção no decorrer dos ciclos de seleção, também ocorreu uma pequena diminuição no ciclo das plantas, estreitando a amplitude de dias para o florescimento desse material.

-Resultados semelhantes a esse de PATERNIANI e ZINSLY(1965), são relatados por MARTIN e HALLAUER(1980). Esses autores reportam o resultado de 7 ciclos de seleção recorrente recíproca para produção de grãos em dois sintéticos de mi lho, onde foi obtido ao lado de um aumento de produção do cruzamento entre as populações após a seleção, uma redução significativa no número de dias do plantio até 50\% do florescimento feminino.

Contrastando com esses resultados, MULAMBA et alii(1983) constataram, após 14 ciclos de seleção massal para produção em uma população de milho, um aúmento na produção de $6,9 \%$ acompanhado por um florecimento mais tardio e um aumento na umidade dos grãos na colheita. 
Das características morfológicas relacionadas com o ciclo da planta, KULESHOV(1932) observou que o número de folhas poderia ser utilizado para agrupar os híbridos americanos e russos em classes de maturação, tendoos híbridos tardios um maior número de folhas que os precoces.

Conclusões semelhantes a essa foram obtidas por CHASE e NANDA(1967). Esses autores estudaram 21 híbridos duplos que representavam toda variação de ciclos dos híbridos cultiva dos. Correlações significativas foram obtidas entre a média de número de folhas por híbridos e a média do número de dias do plantio até a antese. Os autores concluiram que os hibridos de maturação mais precoces tem um menor número de folhas e requerem um menor número de dias até a antese do que os híbridos tardios, em todos os casos avaliados. Também a umidade dos graos na colheita está positiva e significativamente correlacionada tanto com o número de folhas como com o número de dias até a antese.

BRAWN(1968) comenta que a seleção para precocí dade praticada na variedade Gaspé flint, resultou em um material que tipicamente produz 8 folhas e que é, provavelmente, o milho mais precoce do mundo. A continuação da seleção massal para a precocidade não diminuiu ainda mais o número de folhas.

FISCHER et alii(1979) (não publicado) avaliaram ciclos de seleção para reduzir altura da planta na população Tuxpeño Crema I. Os seguintes ciclos foram avaliados: Ori- 
ginal, 69, 99, 12\%, e 15\% ciclos, em 3 densidades de plantio e 3 locais no México em 1978. Os resultados mostraram que, além de uma significativa redução na altura da planta e altura da espiga, ocorreu decréscimo no número total de folhas por planta, diminuição no número de dias para florescimento, tanto mas culino quanto feminino e um aumento na produção de grãos. Sobre esse ganho positivo na produção, os autores comentam que o mesmo pode ter ocorrido devido à eliminação, durante o processo de seleção, de famílias com aparência visual de baixa produ tividade ou vigor. Como esse processo se repetiu por muito tem po, levou a um aumento na produção.

Outro relato de seleção indireta para o flores cimento foi feito por RUSSELL et alii(1979). Esses autores re alizaram 3 ciclos de seleção recorrente para resistência à Ostrinia nubilalis. Na avaliação do resultado constataram que o ciclo 3 foi 0,2 dias significativamente mais precoce na média de todas as populações, tendo ocorrido ainda uma diminuição na altura da planta e da espiga. Segundo os autores, na maioria dos casos onde houve alteração nas frequências gênicas, isto ocorreu para caracteres de alta herdabilidade como, por $\underline{e}$ xemplo, dias para florescimento, altura da planta e altura da espiga, onde a seleção de plantas individuais é relativamente fácil e deve ter ocorrido independentemente do objetivo princi pal da seleção recorrente.

CHASE(1964) fez várias comparações envolvendo híbridos três vias (triplos) que florescem em épocas diferentes, 
mas apresentam porcentagens de umidade semelhante na colheita, assumindo que o número de dias entre o florescimento e a maturação fisiológica foram grosseiramente equivalentes para todos os híbridos. Observou que os híbridos que florescem mais cedo tendem, com grande intensidade, a serem menos produtivos. Há em cada caso, uma relação positiva entre produção e o número de dias do plantio até o florescimento para os híbridos com mesma umidade na colheita e, há um ganho de i bushel de peso seco de grãos/acre para cada acréscimo de um dia no intervalo entre o plantio e o florescimento. O autor considera, então, que no geral pode-se esperar maiores produções de híbridos que flores cem mais tarde e apos o estágio de maturação fisiológica perdern água (secam) rapidamente, do que daqueles que florescem mais cedo e tem uma taxa mais lenta de secagem dos grãos.

TROYER e HALLAUER(1968) avaliaram 10 variedades extremamente precoces e os 45 cruzamentos entre elas. As correlações entre produção e a percentagem de umidade nos grãos $(r=0,86)$ e entre produção e o nümero de dias para o florescimen to $(r=0,81)$ foram positivas e altamente significativas.

HALLAUER e SEARS(1972) relatam os resultados de 4 ciclos de seleção massal para precocidade no composto Eto. U ma amostra desse composto foi plantada no ano de 1963 numa área isolada de 0,20 ha em Iowa e, posteriormente, por ocosião do florescimento, as primeiras 250 plantas a emitirem os estilo-estigmas foram marcadas. Com uma amostra de sementes de ca da planta selecionada foi feito um "bulk", utilizado para o 
plantio no ano seguinte de 0,5 ha isolados, onde novamente foram marcadas as 250 plantas mais precoces para o florescimento feminino. Esse procedimento foi repetido para a obtenção dos próximos ciclos.

A seleção massal para florescimento feminino mais precoce no composto Eto foi efetiva, dando um material mais precoce e com espigas mais baixas. Os autores obtiveram um progresso médio para precocidade de 3,8 dias/ciclo, com uma redução de $15 \mathrm{~cm} /$ ciclo na altura da espiga.

Relato bastante interessante envolvendo seleção para precocidade é encontrado em TROYER e BROWN(1972), ten do sido empregada um metodologia semelhante à utilizada no tra balho anteriormente descrito. Os autores trabalharam com 3 sin téticos de milho: dois deles envolvendo germoplasma mexicano cruzado com milhos de Corn Belt e o terceiro envolvendo materiais do Caribe também cruzados com milhos de Corn Belt. A me todologia empregada por esses autores consistia em intercruzar (através de mistura de polém) as 55 plantas mais precoces de um lote de 1.100 plantadas a cada ano, de cada sintético. No ano seguinte um composto balanceado de sementes das plantas pre coces selecionadas era plantado e o procedimento era repetido. Nos dois primeiros ciclos de seleção os lotes foram plantados com uma densidade de 87.000 plantas/ha e, nos ciclos subsequen tes, foram utilizadas 65.000 plantas/ha. Os ensaios de avalia ção desse material foram plantados em 3 densidades nos ano de 1966 e 1967. 
Com relação a dias para o florescimento femini no, que foi carater usado como critério de seleção, os autores obtiveram uma resposta consistente, com redução de 1,8 dia por ciclo de seleção, na média dos sintéticos, anos e densidades u tilizadas. A umidade dos grãos na colheita apresentou uma res posta média de $-1,2$ pontos percentuais de umidade por ciclo. observou-se ainda uma redução média de 7,2 cm por ciclo na altura da espiga, tendo sido ainda reduzida a diferença entre o florescimento masculino e feminino, o que significa que esse método é mais efetivo para reduzir o florescimento feminino do que o masculino. Para produção ocorreram,em média, acréscimos não significativos.

Os autores estimaram também as correlações fenotipicas simples entre florescimento e os demais caracteres a valiados, tendo sido obtidas correlações positivas e significa tivas para: umidade de grãos $(+0,981)$, altura da planta(0,954), altura da espiga $(+0,981)$ e protandria $(+0,932)$. Para produção devido ao ano de 1967 ter sido muito ruim, houve uma inconsistência nas estimativas: para 1966 a correlação foi positiva e não significativa $(+0,445)$ e para 1967 negativa e significativa $(-0,985)$.

TROYER e BROWN(1976) submeteram 7 sintéticos à seleção massal para precocidade, tendo sido empregada uma metô dologia semelhante à empregada no trabalho citado anteriormente. Obteve-se uma redução média de 1,7 dias por ciclo para o florescimento feminino e grandes respostas correlacionadas com 
a precocidade foram obtidas, destacando-se uma redução média de 1,6 pontos percentuais de umidade nos grãos por ciclo, $6,1 \mathrm{~cm}$ na altura da planta, 4,2 cm na altura da espiga e 0,4 dias a me nos de diferença entre o florescimento masculino e feminino. Esses resultados são muito semelhantes àqueles de TROYER e BROWN (1972) .

Os autores comentam que a época de florescimen to interage com o comprimento da estação de cultivo de duas formas geralmente opostas: (1) o número de dias até o florescí mento mede a quantidade de tempo que a planta tem para crescer em tamanho e determina em alto grau a quantidade de área foliar disponível para a fotossintese. Os milhos que florescem mais tarde, usualmente são mais altos com folhas de maior tama nho e em maior número e, em estações longas de cultivo, os mithos tardios geralmente produzem mais que os precoces; (2) o nú mero de dias para florescimento mede inversamente o comprimento do período de énchimento dos grãos. Em estações curtas os milhos precoces tem tempo para completar o periodo de enchimen to dos grãos, o que não ocorre com os milhos tardios. Nesse ca so, os milhos precoces normalmente produzem mais que os milhos tardios.

Uma constatação interessante feita pelos autores foi a de que sintéticos que originalmente florescem após 67 dias da emergência produziram mais na versão selecionada para precocidade. Por outro lado, sintéticos que floresciam 으 riginalmente antes de 67 dias após a'emergência tiveram sua 
produção reduzida com a seleção para precocidade. Com base nis so, os autores sugerem a seleção de genótipos que possuam uma taxa de crescimento vegetativo bastante rápida de forma a atin gir um tamanho ótimo mais cedo, tendo ainda um período de enchi mento dos grãos bastante longo. Essas conclusões contrastam com aqueles de CHASE(1964).

GENTER(1976) fez 10 ciclos de seleção num composto formado por 25 raças de milho mexicanas, tendo obtido após os 10 ciclos, um aumento de $24 \%$ na produção com uma redução de 11 dias no florescimento feminino e 8\% na umidade dos grãos.

TROYER(1976) fez seleção para precocidade em duas populações $\mathrm{F}_{2}$, conseguindo acréṣcimo de 3,4 quintais/ha/ ciclo na produtividade e um decréscimo de 0,6 dias/ciclo no flo rescimento feminino para uma das populações. Para a outra foram obtidos decreścimos de $1 \frac{8}{8}$ na umidade dos grãos, $7 \mathrm{~cm}$ na al tura da planta e 1.,2 dias no florescimento feminino, por ciclo de seleção.

Uma combinação de seleção para precocidade e qualidade de colmo é encontrada no trabalho relatado por TROYER e LARKINS(1985). Esses autores fizeram 11 ciclos de seleção pa ra precocidade em 10 sintéticos tardios de milho, sendo que a partir do 60 ciclo, além da precocidade, foi feita seleção para qualidade de colmo. A avaliação dos 11 ciclos de seleção por 3 anos, mostrou, por ciclo, uma redução de aproximadamente 
1 dia na deiscencia do pólem, 1,4 pontos a menos na porcentagem de umidade dos grãos e um aumento de $5 \%$ na produção. A com paração dos ciclos 0 a 5 (seleção apenas para florescimento) com os ciclos 6 a 11, mostrou que a seleção para qualidade de colmo foi efetiva, enquanto que a seleção para precocidade con tinuou efetiva nestes últimos ciclos, mas com progressos decrescentes.

$$
\text { Portanto evidēncias não faltam da facilidade }
$$
de se obter ganhos significativos na seleção parao carater pre cocidade em milho, bem como das alterações que esse processo trás para diversas outras caracteristicas da planta, relaciona das com florescimento. Por outro lado, não pode ser descartada a possibilidade de se combinar critérios de seleção visando outras caracteristicas.

Nenhum trabalho foi encontrado na literatura relatando seleção para o aumento do ciclo, ou seja, para obten ção de plantas de'milho mais tardias. 


\section{MATERIAL E MÉTODOS}

\subsection{Material}

Foi utilizado um composto de milho, denominado ESALQ-PB-1, sintetizado.no Departamento de Genética da ESALQUSP. Segundo PATERNIANI et alii (1977) esse composto foi obti do a partir do cruzamento de sete populações a saber: Tuxpeño Crema I, Mezcla Amarilla, Eto Blanco Planta Baja e Antigua Gru po 2, obtidos do CIMMYT; MEB obtido da Seção de Genética do IAC e, Piracar e Cateto Argentina-Uruguai, obtidos no Instituto de Genética da ESALQ. Material variável quanto ao tipo de semente, porém promissor quanto ao potencial para a obtenção de milhos de porte baixo e de boa produtividade.

\subsection{Métodos}

Todo o trabalho de seleção foi realizado em $\mathrm{P} \underline{\underline{i}}$ racicaba-SP, na ārea experimental do Departamento de Genética da ESALQ-USP. 
3.2.1. Obtenção do I ciclo de seleção

No ano agrícola $1976 / 77$, foi plantado um lote com aproximadamente 5.000 plantas do composto ESALQ-PB-1, tendo sido utilizada uma densidade de 5 plantas $/ \mathrm{m}^{2}$. Por ocasião do florescimento, foram selecionadas as primeiras 160 plantas e as últimas 160 plantas a emitirem os estilo-estigmas, tendo si do cruzadas duas a duas (sib) as plantas selecionadas, dentro de cada grupo (precoces e tardias), desprezando-se $\circ$ macho. Com isso, daquele lote foram colhidas separadamente as 80 espi gas oriundas do grupo de plantas mais precoces e as 80 representativas do grupo de plantas mais tardias, que deram origem ao I ciclo de seleção para precocidade e I ciclo de seleção pa ra plantas tardias, respectivamente.

Uma amostra equitativa de cada espiga foi toma da dentro de cada grupo para, após homogeneização da mistura mecânica, formar uma amostra de sementes para cada grupo selecio nado (precoce e tardio).

3.2.2. Obtenção do II ciclo de seleção

No ano agrícola de 1977/78, dois lotes foram plantados: O primeiro com sementes remanescentes do I ciclo de seleção para plantas precoces e o segundo com sementes do I cí clo de seleção para plantas tardias. Os lotes eram compostos por aproximadamente 3.000 plantas cada um, numa densidade de 50.000 plantas/ha. 
Por ocasião do florescimento, no primeiro lote, as 160 plantas mais precoces foram cruzadas duas a duas, desprezando-se o macho. O mesmo foi feito para o segundo lote, quando foram selecionadas as 160 plantas mais tardias.

Desse modo, 80 espigas foram colhidas de cada lote que, após amostradas e misturadas, formaram duas amostras de sementes, representando II ciclo de seleção para plantas pre coces e II ciclo de seleção para plantas tardias, respectivamente ao primeiro e segundo lotes plantados.

3.2.3. Obtenção do III ciclo de seleção

No ano agrícola de $1978 / 79$ outros dois lotes fo ram plantados no-mesmo esquema anterior, utilizando-se sementes do II ciclo de seleção. Devido a problemas havidos a campo, o lote plantado com sementes do II ciclo de seleção para plantas tardias foi perdido. Desse modo, neste ano foi obtido apenas o III ciclo' de seleção para plantas precoces, tendo si do adotado procedimento idêntico àquele utilizado na obtenção do ciclo anterior.

\subsubsection{Avaliação experimental}

Em 1979/80 foram instalados ensaios de competi ção visando avaliar o progresso obtido e o comportamento de di versos outros caracteres da planta nos diversos ciclos de sele ção . 
Foram avaliados: a população original, ciclos I, II e III de seleção para precocidade, ciclos I e II de sele ção para plantas tardias e uma testemunha, Hmd-7974, que é um híbrido duplo semi-dentado amarelo, de ciclo normal, da Secreta ria da Agricultura de São Paulo.

Esses 7 tratamentos foram avaliados em dois en saios no delineamento de Blocos ao Acaso, um instalado na Está ção Experimental de Anhumas, distrito de Anhumas, município de Piracicaba-SP, com 10 repetições, perfazendo um totalde 70 par celas; o outro ensaio foi instalado em área do Departamento de Genética da ESALQ, em Piracicaba-SP, com 8 repetições, num total de 56 parcelas. Em ambos os ensaios foram utilizados parcelas de $10 \mathrm{~m}^{2}$, constituidas por uma linha de 10 metros de com primento espaçadas entre si por $1 \mathrm{~m}$, com número ideal de 50 plantas por parcela.

Nos dois ensaios foram avaliados os caracteres florescimento feminino, número de plantas por parcela ("stand"), altura da planta, altura da espiga, número de espigas, peso e umidade dos grãos, para cada parcela individualmente.

O florescimento feminino corresponde ao número de dias decorridos do plantio até a data em que 50\% das plantas da parcela haviam emitido os estilo-estigmas.

A altura da planta foi tomada em 10 plantas ao acaso de cada parcela, através da medida do nível do solo até a última folha (folha bandeira), fazendo-se posteriormente a mé 
dia aritmética,representativa da parcela. Da mesma forma e $\underline{u}$ tilizando-se as mesmas 10 plantas, foi anotada a altura da espiga, que é a medida do nivel do solo até a inserção da espiga superior.

Como medida de prolificidade, foi calculado o indice de espigas, obtido pela divisão do númerode espigas con tadas por parcela na colheita, pelo "stand" observado na respectiva parcela.

A umidade de grãos foi feita a partir de uma amostra de 100 gramas retirada de cada parcela após a pesagem dos grãos, mantida em recipiente impermeável para homogeneização por 24 horas. Em seguida foi determinada a umidade em um aparelho "Steinlite", modelo G.

Os pesos de grãos por parcela obtidos no campo, foram corrigidos para uma umidade uniforme de $15,5 \%$ através da fórmula:

$$
\begin{aligned}
& \mathrm{PC}_{15,5 \%}=\frac{\mathrm{PC}(1-\mathrm{U})}{0,845}-\text { onde } \\
& \mathrm{PC}_{15,5 \%}=\begin{array}{l}
\text { peso observado no campo corrigido pa } \\
\text { ra } 15,5 \% \text { de umidade; }
\end{array} \\
& \mathrm{PC}=\text { Peso de graos observado no campo; } \\
& \mathrm{U}=\text { Umidade dos grãos na colheita. } \\
& \text { Os pesos de grãos corrigidos para umidade, fo- }
\end{aligned}
$$
ram então corrigidos para um "stand" ideal de 50 plantas por parcela, pela fórmula proposta por zUBER (1942), que è a se- 
guinte:

$$
\begin{aligned}
& \mathrm{PCC}=\mathrm{PC}_{15,5 \%} \times \frac{\mathrm{H}-0,3 \mathrm{~F}}{\mathrm{H}-\mathrm{F}} \text {, onde: } \\
& \text { PcC = Peso de campo corrigido para 15,5\%.de u- } \\
& \text { midade e "stand" ideal de } 50 \text { plantas; } \\
& \mathrm{H}=\text { "Stand" ideal (no caso, } 50 \text { plantas) por par } \\
& \text { cela e, } \\
& F=\text { Nümero de falhas observadas por parcela (no } \\
& \text { caso, } 50 \text { menos o "stand" observado). }
\end{aligned}
$$

Desse modo, os dados referentes a produção apre sentados nos resultados, correspondem ao peso de grãos em quilogramas por parcelas de $10 \mathrm{~m}^{2}$, corrigido para umidade de $15,5 \%$ e "Stand" ideal de 50 plantas.

\subsubsection{Añálise estatística}

Para cada ensaio, foi feita a análise de variân cia de acordo com o delineamento de blocos ao acaso, procurando-se isolar o eféito da testemunha na comparação entre os ciclos, através do desdobramento dos graus de liberdade de trata mentos entre: ciclos de seleção e ciclos de seleção "vs" testemunha. Desse modo, o quadrado médio da fonte de variação ciclos de seleção estima apenas a variância havida entre o compor tamento dos 3 ciclos de seleção para precocidade, 2 ciclos para plantas tardias e população original.

Foram analisados para cada ensaio os caracte-

res: produção $\left(\mathrm{Kg} / 10 \mathrm{~m}^{2}\right)$, florescimento feminino (dias), umida de de grãos na colheita (\%), altura da planta (m), altura da 
espiga (m) e indice de espigas (espigas/plantas).

\subsubsection{Estudo detalhado do progresso}

Foi feito um estudo do progresso devido à sele ção, de acordo com um modelo linear que inclui: a) a média da população original (m) e, b) o ganho por ciclo devido à seleção para plantas precoces $\left(G_{p}\right)$ e para plantas tardias $\left(G_{t}\right)$. As estimativas dos parâmetros e as respectivas somas de quadrados foram obtidas pelo método dos quadrados mínimos. Na análise da variância foram testadas as seguintes hipóteses: a) $G_{p}=0$; b) $G_{t}=0$ ec) $G_{p}=G_{t}$.

Dessa forma, esses parâmetros foram estimados para cada característica avaliada e, como a seleção foi feita apenas para o florescimento feminino, a análise das alterações ou ganhos verificados nos outros caracteres foi tomada como in dicativo das respostas associadas à alteração do ciclo da plan ta.

Esse estudo foi feito separadamente para cada experimento ou local de teste. 


\section{RESULtADOS}

Os resultados são apresentados individualmente para cada local onde foi feita avaliação: Anhumas e Piracicaba. As condições gerais de clima e solo foram diferente de um local para outro, com reflexos nos resultados.

Verificou-se o impedimento teórico da realização da análise conjunta para alguns dos caracteres avaliados, por não haver homogeneidade dos quadrados médios residuais das análises simples', conforme recomendação de PIMENTEL GOMES $(1973)$

\subsection{Resultados dos Ensaios de Competição}

Na Tabela 1 são apresentados os resultados observados no ensaio conduzido em Anhumas no ano agrícola de 1979/80. Os valores apresentados nesta tabela correspondem à média das 10 repetições utilizadas. São apresentados também a média do ensaio, o coeficiente de variação e o valor do teste de Tukey (5\%) para cada caracteristica avaliada. 
o coeficiente de variação obtido para produção foi de 22,8\%; para as demais caracteristicas os coeficientes de variação estão dentro da faixa de valores normalmente obtidos na experimentação agrícola.

O solo na Estação Experimental de Anhumas é de baixa fertilidade e estava em processo de correção nessa época. Aliado a isso, no ano agrícola 1979/80 ocorreu uma relativa es cassez de chuvas naquele local, o que contribuiu para um mau desenvolvimento geral das plantas, com reflexos em diversas ou tras características avaliadas tais como: altura da planta, al tura da espiga, indice de espigas e florescimento feminino.

Os resultados observados no ensaio conduzido em Piracicaba estão na Tabela 2, cujos dados correspondem à mé dia de 8 repetições. Também são mostrados nessa tabela a média do ensaio, o coeficiente de variação e o valor do teste de Tukey (5\%) para cada característica avaliada.

O coeficiente de variação obtido para o carater produção foi de $14,1 \%$, podendo ser considerado médio em termos de experimentação agrícola. Para as demais características avaliadas, os coeficientes de variação estão dentro da faixa de valores normalmente obtidos para esses caracteres.

4.2. Análise da Variância

A análise da variância e significância dos qua 
drados médios estimados para o ensaio conduzido em Anhumas, en contram-se na Tabela 3. Foram analisados todos os caracteres avaliados e as significâncias dos quadrados médios apontadas foram obtidas pelo teste F.

Para O carater produção obteve-se um F signifi cativo ao nivel de $1 \%$ de probabilidade para tratamentos que, 0 desdobramento dos gráus de liberdade dessa fonte, mostrou ser devido a diferença entre ciclos e testemunha, não se detectando diferenças significativas entre os ciclos de seleção. A mes ma situação ocorreu na análise dos caracteres altura da planta e indice de espigas, onde a diferença detectada entre tratamen to era devida ao efeito da testemunha e não entre os ciclos de seleção.

Para a característica umidade de grãos não se detectou diferença significativa entre os tratamentos avalia-dos.

Diferenças significativas ao nivel de $1 \%$ de pro babilidade entre ciclos de seleção e também para ciclos "vs" testemunha, foram detectadas para os caracteres florescimento e altura de espiga.

Na Tabela 4 se encontra a análise da variância para o ensaio conduzido em Piracicaba. Nos resultados deste ensaio não se detectou diferenças significativas entre os tratamentos para os caracteres produção e indice de espigas. Para a característica umidade de grãos, foi detectada diferença 
significativa apenas em testemunha "vs" ciclos de seleção, ao nível de 5\% de probabilidade.

Para as caracteristicas florescimento, altura da planta e altura da espiga, foram detectadas diferenças sig nificativas tanto entre os ciclos de seleção quanto na compara ção de ciclos "vs" testemunha.

Comparando-se os resultados da análise da variância para os dois locais, Anhumas e Piracicaba, nota-se uma consistência para algumas das características avaliadas. Tal ocorre com florescimento e altura da espiga, que mostraram diferenças significativas ao nível de 1\% de probabilidade entre ciclos de seleção, nos dois locais.

Para o carater altura da planta, diferenças en tre ciclos de seleção não detectadas em Anhumas, o foram em Pi racicaba. Produção e indice de espigas que haviam mostrado sig nificância na comp̣aração ciclos "vs" testemunha em Anhumas, não mostraram o mesmo no ensaio conduzido em Piracicaba.

A significância, ao nível de 5\% de probabilidą de, detectada na comparação entre testemunha e ciclos de seleção para o carater umidade de grãos em Piracicaba, não foi detectada em Anhumas, provavelmente devido à colheita do ensaio em Anhumas ter sido feita com os grãos apresentando, no geral, $\underline{u}$ midades bastante baixas, o que contribuiu para uma uniformização dos tratamentos quanto a esse carater (Tabela 1). 


\subsection{Estimativas dos Parâmetros}

De acordo com um modelo linear adotado e utili zando-se o método dos quadradosmínimos, foram estimados os parâmetros: média da população original (m), o ganho por ciclo devido à seleção para precocidade $\left(G_{p}\right)$ e o ganho por ciclo devido à seleção para plantas tardias $\left(G_{t}\right)$, para o carater florescimento feminino, que foi o critério de seleção utilizado,e para todas as outras características avaliadas: produção, umidade dos grãos na colheita, altura da planta, altura da espiga e Indice de espigas.

As estimativas desses parâmetros com base nos resultados do ensaio de Anhumas estão na Tabela 5. Na Tabela 6 são mostradas às estimativas dos quadrados médios das hipōte ses testadas e dos desvios do modelo adotado, obtidas pela mes ma metodologia.

O 'ganho obtido por seleção para precocidade $\left(G_{p}\right)$ para o carater florescimento foi o único estatisticamente significativo, sendo que a comparação deste com o ganho devido à seleção para plantas tardias $\left(G_{t}\right)$ para essemesmo carater, $f_{\underline{i}}$ cou próximo da significância pelo teste $F$ ao nível de 5\% de pro babilidade.

Os progressos estimados para os demais caracte res e, ainda, as comparações entre eles para cada característi ca, com base nos resultados de Anhumas, foram todos não significativos. Também os desvios do modelo adotado não mostraram 
significância.

Na Tabela 7 são mostradas as estimativas dos parâmetros para o ensaio conduzido em Piracicaba. Na Tabela 8 estão as estimativas dos quadrados médios das hipóteses testadas e dos desvios do modelo adotado, obtidos pelo método dos quadrados mínimos para todas as características avaliadas nesse local.

Para o carater florescimento, foram obtidas signi ficâncias dos quadrados médios do ganho devido à seleção para precocidade $\left(G_{p}\right)$ e para a comparação deste com o ganho devido à seleção para plantas tardias $\left(G_{t}\right)$, sendo a primeira ao nível de $1 \%$ e a segunda ao nível de 5\% de probabilidade. Não houve significância para desvios do modelo.em nenhuma das caracterís ticas avaliadas.

As significâncias das estimativas dos ganhos fọ ram bastante consi,stentes entre os dois locais. Entretanto, as magnitudes das estimativas do ganho devido à seleção para precocidade $\left(G_{p}\right)$ diferiram: para Anhumas esta foi de $-4,48$ dias por ciclo e para Piracicaba foi de $-2,34$ dias por ciclo.

Para as características umidade de grãos e índice de espigas, as estimativas de $G_{p}$ e $G_{t}$, embora não signifi cativas, foram positivas para Anhumas e negativas para Piracicaba. Também ocorreu uma inversão de sinais entre os locais nas estimativas de $G_{p}$ para altura da planta.

A regressão linear para o carater florescimen- 
to se encontra representada no Gráfico 1. As equações foram montadas de acordo com a modelo adotado, segundo o qual:

$$
\hat{\mathrm{Y}}=\mathrm{m}+\mathrm{G}_{\mathrm{p}} \cdot \mathrm{X} \text {, para os ciclos de seleção pa- }
$$

ra precocidade e,

$$
\hat{\mathrm{Y}}=\mathrm{m}+\mathrm{G}_{\mathrm{t}} \cdot \mathrm{X} \text {, para os ciclos de seleção pa- }
$$

ra plantas tardias.

Nas duas equações $\underline{X}$ corresponde a ciclo de seleção. 


\section{DISCUSSÃO}

\subsection{Seleção para Florescimento}

Alguns caracteres como o florescimento, masculino e feminino, a maturação fisiológica dos grãos e a umidade dos grãos na colheita, todos correlacionados entre si, podem ser utilizados como critério na avaliação de ciclo em milho. Outros caracteres podem fornecer uma indicação indireta de ciclo, como por exemplo, número de folhas por planta ou a altura da planta

Dessa forma, a seleção para alteração do ciclo em milho poderia adotar qualquer uma dessas características co mo critério, com maior ou menor chance de progresso em cada uma, conforme fica evidenciado na literatura (CHASE e NANDA (1967); BRAWN(1968); DANIEL et alii(1974); SHEHATA et alii (1976) e FISCHER et alii(1979)).

Os trabalhos de DANIEL et alii(1974) e SHEHATA et alii(1976), mostram estimativas que permitem a expectativa 
de ganhos significativos com a seleção para florescimento, especialmente tomando-se como critério o florescimento feminino.

A seleção massal divergente para florescimento feminino, resultou em progressos significativos para precocidade, com ganhos da ordem de $-4,5$ dias por ciclo na estịma tiva com base nos resultados de Anhumas e de $-2,3$ dias por ci clo para Piracicaba. Ambos foram significativos ao nível de 1\% de probabilidade e se colocam entre os maiores relatados na literatura, que mostra reduções no nümero de dias para oflores cimento variando de 0,6 dias por ciclo (TROYER, 1976) até 3,8 dias por ciclo (HALLAUER e SEARS, 1972). Para os dois locais os resultados mostram uma consistente redução em cada ciclo de seleção para precocidade.

Houve grandes diferenças de condições entre os dois locais avaliados, o que pode ser evidenciado comparando-se, por exemplo, as médias de produtividade dos ensaios: 2, 24 $\mathrm{Kg} / 10 \mathrm{~m}^{2}$ em Anhumás e $4,28 \mathrm{Kg} / 10 \mathrm{~m}^{2}$ em Piracicaba. As condições adversas verificadas em Anhumas, também se refletiram no ciclo dos materiais avaliados, dilatando as diferenças entre $\underline{e}$ les, para esse carater. A testemunha utilizada, Hmd-7974, necessitou aproximadamente 1.0 dias mais para florescer em Anhumas que em Piracicaba.

Comparando-se o comportamento dos ciclos de se leção entre os dois locais, verifica-se que para o ciclo origi nal houve uma diferença de aproximadamente 13 dias enquanto que 
para o III ciclo de seleção para precocidade essa diferença foi de 5,6 dias. Isso mostra que os tratamentos mais precoces foram menos afetados pelas condições adversas de Anhumas que os mais tardios. Com isso, a estimativa de $G_{p}$ para o carater flo rescimento foi maior para Anhumas. Resultados semelhantes foram relatados por TROYER e BROWN (1972).

Com relação à seleção para plantas tardias, fo ram obtidos ganhos não significativos de 0,12 dias por ciclo para Anhumas e 0,24 dias por ciclo para Piracicaba. Não se en controu nenhum trabalho na literatura relatando seleção para aumentar o ciclo, para que se pudesse fazer comparações.

Em função dos resultados obtidos na seleção pa ra precocidade, ainda que se considere apenas os 2 primeiros cí clos, era de se esperar que a metodologia empregadá também fos se efetiva na seleção para aumentar o ciclo, o que não ocorreu.

\subsection{Respostas Correlacionadas}

Vários autores relatam a obtenção de correlações significativas entre caracteres do milho, razão porque é de se esperar que a seleção praticada sobre um carater, leve a alterações nas outras características a ele correlacionadas. In dependente disso, a própria metodologia empregada pode levar a uma seleção indireta para caracteres outros que não o do interesse principal do melhorista. Exemplo disso é o relato de 
RUSSEL et alii(1979) que, selecionando para resistência a Ostrinia nubilalis, obtiveram também uma redução no ciclo das plantas.

Em função do pequeno número de ciclos de seleção avaliados, não foram estimadas as correlações entre o fḷorescimento e as demais caracteristicas anotadas. Nesse caso, as estimativas seriam de baixa precisão, não permitindo conclu sões seguras. Optou-se, então, pelo uso da regressão linear, através da estimativa dos ganhos devido à seleção nos dois sen tidos, para os outros caracteres avaliados além do florescimen to.

\subsubsection{Produção}

Para o caráter produção, não foram detectadas diferenças significativas entre os ciclos de seleção em nenhum dos dois locais avaliados, o mesmo acontecendo com os ganhos de vido à seleção. Os dados da literatura a esse repeito são con traditörios, encontrando-se estimativas de correlação entre flo rescimento e produção positivas em alguns trabalhos (CHASE (1964) ; TROYER e HALLAUER (1968)) e negativas em outros (PATERNIANI e ZINSLY(1965) ; GUNTER(1976) e TROYER(1976)) . Isso ocorre porque a produção, devido à sua baixa herdabilidade, é um carater altamente influenciado pelo ambiente, ao contrário do caráter florescimento que possui alta herdabilidade.

Embora os ganhos devido à seleção estimados pa 
ra produção não tenham sido significativos, observando-se os re sultados nota-se uma tendência de maior produtividade para os tratamentos mais precoces em Anhumas e para os mais tardios em Piracicaba. Tal situação fica patente, comparando-se as magni tudes dos ganhos estimados para os dois locais. Esses resulta dos são comparáveis àqueles de TROYER e BROWN(1972) que, para um mesmo conjunto de materiais, obtiveram correlação entre flo rescimento e produção positiva num ano favorável e negativa no ano seguinte, que apresentou condições adversas ao bom desenvol vimento das plantas.

Também diferenças entre os germoplasmas podem resultar em diferentes respostas para o carater produção quan do submetidos à șleção para precocidade. TROYER e BROWN(1976) observaram acréscimos na produtividade com a seleção em sintéticos originalmente mais tardios e decréscimos naqueles originalmente mais precoces. Assim sendo, a obtenção de ređuções significativas no iciclo do composto ESALQ-PB-1, semalterar sig nificativamente sua produção, deve ser considerado um fato positivo que realça o potencial desse composto. A continuação da seleção para precocidade por mais alguns ciclos, poderia forne cer melhores informações a esse respeito.

5.2.2. Umidade de grãos na colheita

o caráter umidade de grãos é positivamente cor relacionado com dias para florescimento (CHASE e NANDA(1967) e 
TROYER e BROWN(1972)), razão porque esperava-se alterações nesse caráter devido à alteração do ciclo. Contrariando essa expectativa, não se obteve nenhuma alteração significativa na umidade dos grãos, apesar da alteração do ciclo. Diversos trabalhos mostram, ao lado de substânciais ganhos na redução do nú mero de dias para florescimento, significativa diminuição na u midade dos grãos na colheita (TROYER e BROWN(1972); TROYER e BROWN(1976); GENTER(1976) e TROYER(1976)).

A avaliação desse carāter em Anhumas ficou pre judicada devido à colheita ter sido feita muito tarde, quando os tratamentos já apresentavam umidade de grãos bastante bai xas, que contribuiram para uma uniformidade entre estes. Entre tanto, também para Piracicaba onde a colheita foi efetuada com os grãos mais úmidos, os valores obtidos para umidade estão pró ximos, apenas se detectando significância para a comparação ci clos "vs" testemunha.

Esses resultados contrariam todas as expectati vas com base nos resultados relatados na literatura e já citados, uma vez que significativos ganhos obtidos na seleção para precocidade no presente trabalho, não provocaram alteração alguma na umidade dos grãos.

5.2.3. Altura da planta e altura da espiga

Para altura da espiga, foram detectadas diferenças significativas entre os ciclos de seleção nos dois lo- 
cais avaliados. Para altura da planta detectou-se diferença significativa apenas em Piracicaba. TROYER e BROWN(1972) estimaram as correlações entre florescimento e esses caracteres, tendo obtido 0,954 para altura da planta e 0,981 para altura da espiga, o que mostra que a seleção praticada sobre o florescimento também leva a alterações no porte da planta.

Entretanto, as estimativas dos ganhos devido à seleção, foram todas não significativas, contrariando diversos resultados encontrados na literatura (TROYER e BROWN (1972); HALLAUER e SEARS(1972); TROYER e BROWN(1976) e TROYER(1976)). A obtenção de diferenças significativas entre ciclos de seleçao para esses caracteres, ainda que para altura da planta tal não tenha sido obtida em Anhumas, mostra que a seleção pratica da alterou a altura da planta e altura da espiga, mas essas al terações ocorreram de maneira errática ao longo dos ciclos, re sultando em ganhos não significativos.

Na sintese do composto utilizado, foi dado ênfase na escolha de populações de baixo porte que aliado ao nūmero reduzido de ciclos de seleção avaliados, constitiuem fatores que podem ter contribuido para a não obtenção de alterações consistentes na altura da planta e espiga ao longodos ciclos.

\subsubsection{Indice de espigas}

O carater indice de espigas foi avaliado como medida de prolificidade. Na literatura consultada, não há re- 
lato de respostas correlacionadas à seleção para florescimento para esse carater.

Nenhuma diferença significativa foi verificada entre os ciclos de seleção para os dois locais avaliados, no to cante a esse carater. Também os ganhos estimados foram não sig nificativos e de magnitudes muito pequenas, apenas se verificando uma inversão de sinais tanto para $G_{p}$ quanto para $G_{t}$ entre os dois locais. Por outro lado, o fato de não ter se conseguido um bom "stand" nos dois ensaios, especialmente para os tratamentos I ciclo de seleção para precocidade e I ciclode se leção para plantas tardias, prejudicou a precisão deste dado.

\subsection{Metodologia Empregada}

A seleção massal empregada no presente trabalho foi bastante efetiva para reduzir o número de dias até o florescimento, como mostram os resultados altamente significativos e a exemplo: de diversos trabalhos encontrados na literatura (HALLAUER e SEARS(1972); TROYER e BROWN(1972); TROYER e BROWN(1976); GENTER(1976) e TROYER(1976)), sendo que essa meto dologia não apresentou resultado algum na seleção para plantas tardias.

Considerando que no presente trabalho foram avaliados apenas dois ciclos de seleção para plantas tardias e que nenhum relato para esse tipo de seleção foi encontrado na literatura, torna-se difícìl inferir se a seleção massal, ain- 
da que praticada sobre os dois sexos como no caso presente, poderia ser efetiva para aumentar o número de dias para o flores cimento. Observações feitas pelo autor durante o desenvolvimen to dos trabalhos para obtenção dos ciclos de seleção, mostram que a execução a campo desse tipo de seleção é mais difícill e, provavelmente, menos precisa que a seleção de plantas precoces. Um método de seleção baseado em progênies, deveria ser mais efetivo para o aumento do ciclo, possibilitando uma avalia ção melhor das respostas correlacionadas e essa alteração.

Contrariando o esperado, os ganhos significatí vos obtidos para o carater florescimento não levaram a altera ções significativas e consistentes ao longo dos ciclos em nenhum outro carater. Diversos fatores devem ter contribuido pa ra que isso se verificasse, entre os quais, o pequeno número de ciclos de seleção avaliados, o que fez com que, embora se notas se diferenças entre os ciclos e, no caso de alguns caracteres, até uma certa tendência de comportamento, essas diferenças apa recem desordenadas, fruto inclusive da variabilidade existente dentro dos ciclos iniciais de seleção. A utilização de diferentes densidades de plantio, principalmente mais altas, poderia favorecer a obtenção de respostas mais consistentes, discriminando melhor os ciclos de seleção.

Com relação a produção, alguns trabalhos tem re latado acréscimos nesse carater associados com a redução do ci clo (TROYER e BROWN(1976) e FISCHER et alii(1979)). No caso presente, a seleção praticada para reduzir o ciclo foi efetiva 
para esse carater, não alterando a produção. Com base nisso, a aplicação de um método combinado de seleção para precocidade, seguido de uma seleção massal para produtividade, deveria ser efetiva no melhoramento para essas duas características no com posto ESALQ-PB-1.

A diferença entre o número de dias para o florescimento masculino e feminino tem sido relatada como uma característica associada a tolerância a "stress", quer seja por falta de água, ou mesmo provocado por altas densidades de plan tio (TROYER e BROWN(1972 e 1976)). Assim sendo, seria interes sante em trabalhos futuros a avaliação dessa característica, $\underline{u}$ ma vez que aqueles autores também constataram uma redução da mesma associada à seleção para precocidade.

Outro carater para o qual se deveria dar atenção e a maturação fisiológica dos grãos. Com essa avaliação, teria-se um panorama mais detalhado do período reprodutivo das plantas, possibilitando conhecer melhor como a seleção efetuada sobre o período até o florescimento (vegetativo), afeta as diversas fases do período seguinte (reprodutivo). A. avaliação do número de folhas complementaria este estudo. 
6. CONCLUSÕES

Os resultados, indicam as sequiintes conclusões:

1. A seleção para precocidade foi efetiva, ten do sido obtidos ganhos de 4,48 dias por ciclo na avaliação feí ta em Anhumas e 2,34 dias por ciclo na avaliação feita em Pira cicaba, ambos estatisticamente significativos.

2. A seleção para aumentar o ciclo, resultou em ganhos de 0,12 dia's por ciclo para os resultados de Anhumas e 0,24 dias por ciclo para Piracicaba, ambos estatisticamente não significativos.

3. A redução substancial do ciclo devido à seleção para precocidade, não alterou a produtividade.

4. Para os demais caracteres, nenhum progresso significativo foi obtido, embora tenha se detectado alterações não consistentes ao longo dos ciclos para altura da planta e al tura da espiga. 
7. IITERATURA CITADA

BRAWN, R.I., 1968. Breeding corn for earliness. Proc. XXIII Ann. Corn and Sorghum res. conf., 23: 59-66.

CHASE, S.S., 1964. Relation of yield and number of days from planting to flowering in early maturity maize hybrids of equivalent grain moisture at harvest. Crop Science, Mad, $\underline{4}$ : $111-112$.

CHASE, S:S. e D.K! NANDA, 1967. Number of leaves and maturity classification in Zea mays L.. Crop Science, Mad. 7: 431432 .

DANIEL, L., 1972. Biometrical and genetical analisys of flowering time in maize. Plant Breed. Abs., Cambridge, $\underline{45}$ : 272 .

DANIEL, L., 1973. Inheritance and genetic variation of flowering time in Zea mays L.. Plant Breed. Abs., Cambridge, $\underline{45}$ : 295 . 
DANIEL, L., I. BATTAY e F. DEAK, 1974. Investigation of the inheritance of flowering time in a diallel cross of imbred lines of sweet corn (Zea mays L.). PLant Breed. Abs., 47: 451 .

De LOUGHERY, R.L. e R.K. CROOKSTON, 1979.. Harvest index of corn affected by population density, maturity rating, and environment. Agron. Jour., Mad., 71: 577-580.

FISCHER, K.S., E.C. JOHNSON e G. EDMEADS, 1979. Evaluation of cycles of selection for reduced plant height in Tuxpeño Crema I. CIMMYT (não publicado).

GARDNER, C.O., P.H. HARVEY, R.E. COMSTOCK e H.F. ROBINSON, 1953. Dominance of genes controlling quantitative characteres in maize. Agron. Jour.. Mad. $\underline{45}$ : 186-191.

GENTER, C.F., 1976. Mass selecion in a composite of intercrosses of mexican races of maize. Crop. Spcience, Mad,. 16: $5.56-558$.

HALLAUER, A.R. e J.H. SEARS, 1972. Integranting exotic germoplasm into Corn Belt maize breeding programs. Crop Science, Mad. 12: 203-206.

KULESHOV, N.I., 1932. Behavior of american corn strains and hybrids in USSR. J.Am. Soc. Agron., Madison, 24: 416-417. MARTIN, J.M. e A.R. HALLAUER, 1980. Seven cycles of reciprocal recurrent selection in BSSS and BSCB1 maize populations. Crop Science, Mad., 20: 599-603. 
MULAMBA, N.N., A.R. HALLAUER e O.S. SMITH, 1983. Recurrent selection for grain yield in a maize population. Crop Science, Mad. 23: 536-540.

PATERNIANI, E. e J.R. ZINSLY, 1865. Efeito do melhoramento do milho no ciclo das plantas. Ciēncia e Cultura, são Paulo, 17: 146 .

PATERNIANI, E., J.R. ZINSLY e J.B. MIRANDA Fo, 1977. Populações melhoradas de milho obtidas pelo Instituto de Genética. Relatório Científico do Instituto de Genética - ESALQ-USP, Piracicaba, 11: 108-113.

PATIL, S.J. 1977. Genetic analysis of resistance to Helmonthosporium turcicum Pass. in relation to maturity yield and yielld components in Zea mays L.. Mysore Jour of Agr. Sci., Karnataka, 11: 425-426.

PIMENTEL GOMES, F. 1973. Curso de Estatistica Experimental. $5 \%$ ed. São Paulo, Livraria Nobel S.A. 430 p..

RUSSEL. W.A., G.D. LAWRENCE e W.D. GUNTHERIE, 1979. Effects of recurrent selection for european corn borer resistance on other agronomic characters in synthetic cultivars of maize. Maydica, Bergamo, 24: 33-47.

SETTY, A.N., 1975. Genic architeture of yield and its components in Zea mays L.. Mysore Jour. of Agr. Sci., Karnataka, 9: $356-357$. 
SHEHATA, A.H., S.I SALAMA e M.A. KHALIFA, 1976. Estimates of maturity and their implications to yield improviment in maize. Egypt. J Genet. Cytol., Alexandria, 5: 248-256.

STANLEY, R.L. Jr e F.M. RHODES, 1975. Response of corn (Zea mays L.) to population and spacing with plow-layer soil water manegement. Proc. Soil and Crop. Sci. Soc. of Flor. 34: $127-130$.

TROYER, A.F., 1967. Yield as influenced by maturity and popula tion. Proc. of the XXII Ann hybrid corn Ind. Res. Conf. 91-98.

TROYER, A. F. e A.R. HALLAUER, 1968. Analysis of diallel set of early flint varieties of maize. Crop. Science., Mad., 8: 581 -584 .

TROYER, A.F. E J.R. LARKINS, 1985. Selection for early flowering in corn: 10 late synthetics. Agron Abstr.,Madison 1985 Annual Meetings.

TROYER, A.F. E W.L.BROWN, 1972. Selection for early flowering in corn. Crop. Science,. Mad., 12: 301-304.

TROYER, A.F. e W.L. BROWN, 1976. Selection for early flowering in corn. Seven late Synthetics. Crop. Science, Mad., 16: 767-772.

TROYER A.F., 1976. Selection for early flowering in corn III (18 $\mathrm{F}_{2}$ populations) Agron. Abstr., Madison, 63. 
YANG, Y. K., 1949. A study on the nature of genes controlling hybrid vigor, as it affects silking time and height in maize Agron. Jour., Madison, $\underline{41}: 309-312$.

ZUBER,M.S., 1942. Relative efficiency of incomplete block designs using corn uniformity trial data. Agron. Jouor., Madison, $34: 30-47$. 
8. TABELAS E GRAFICO DE RESULTADOS 


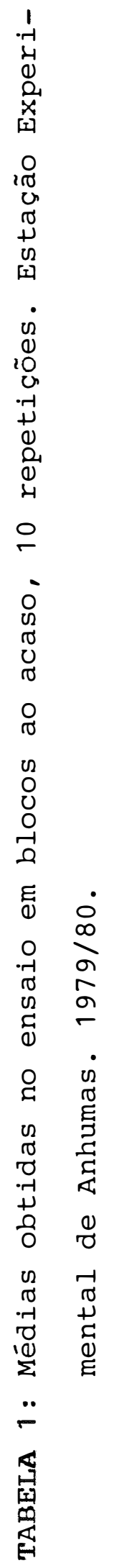

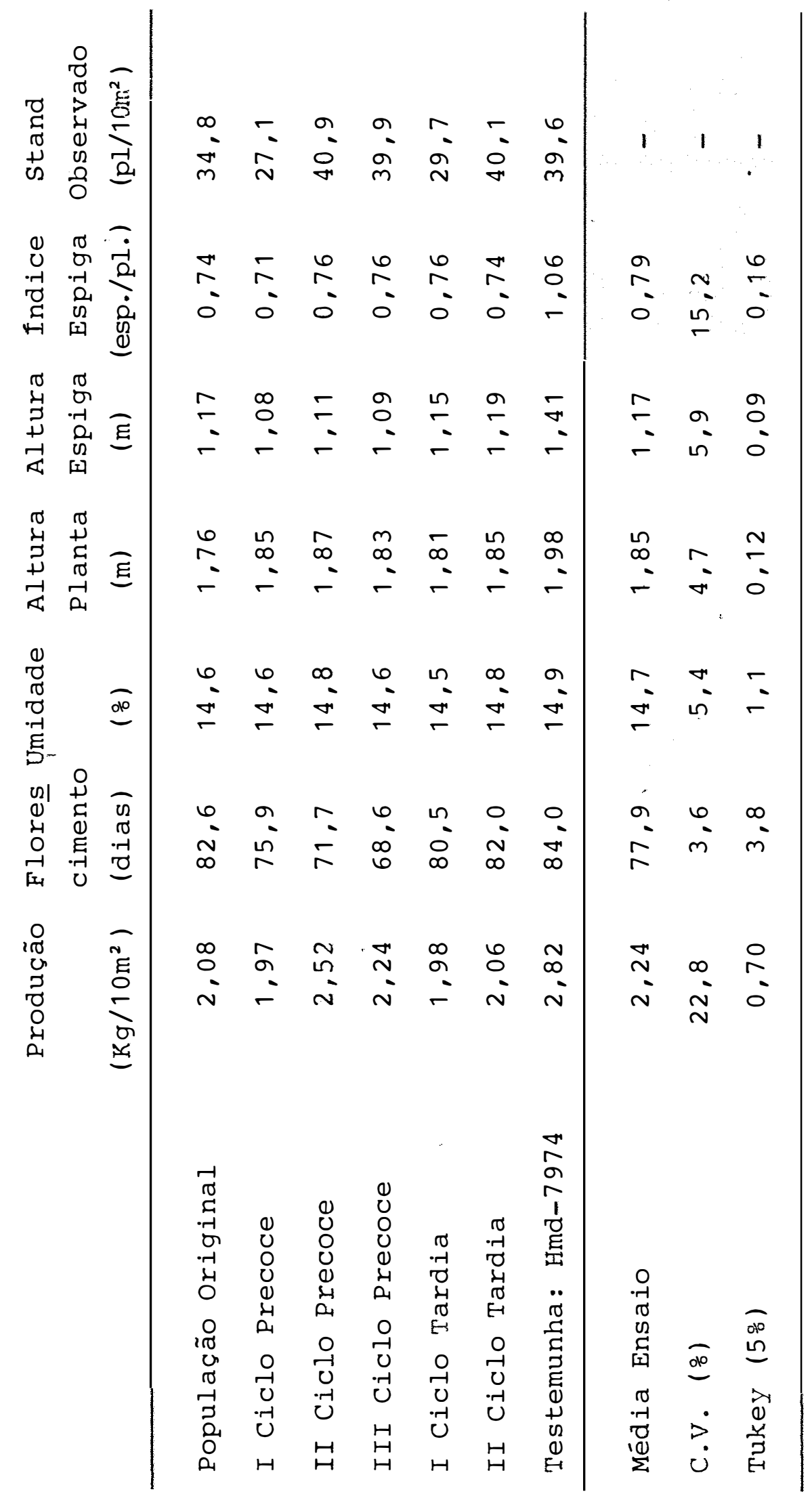




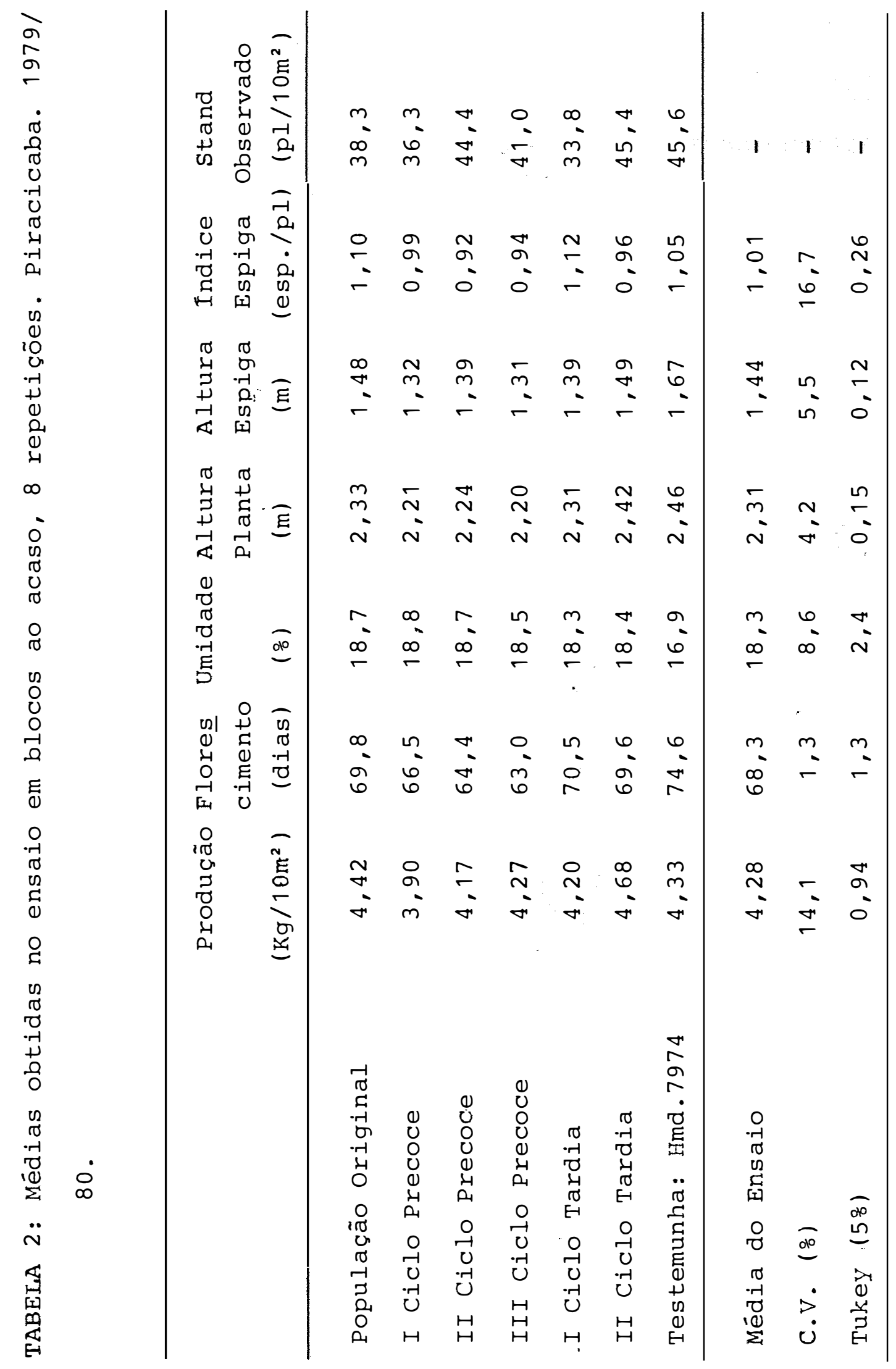




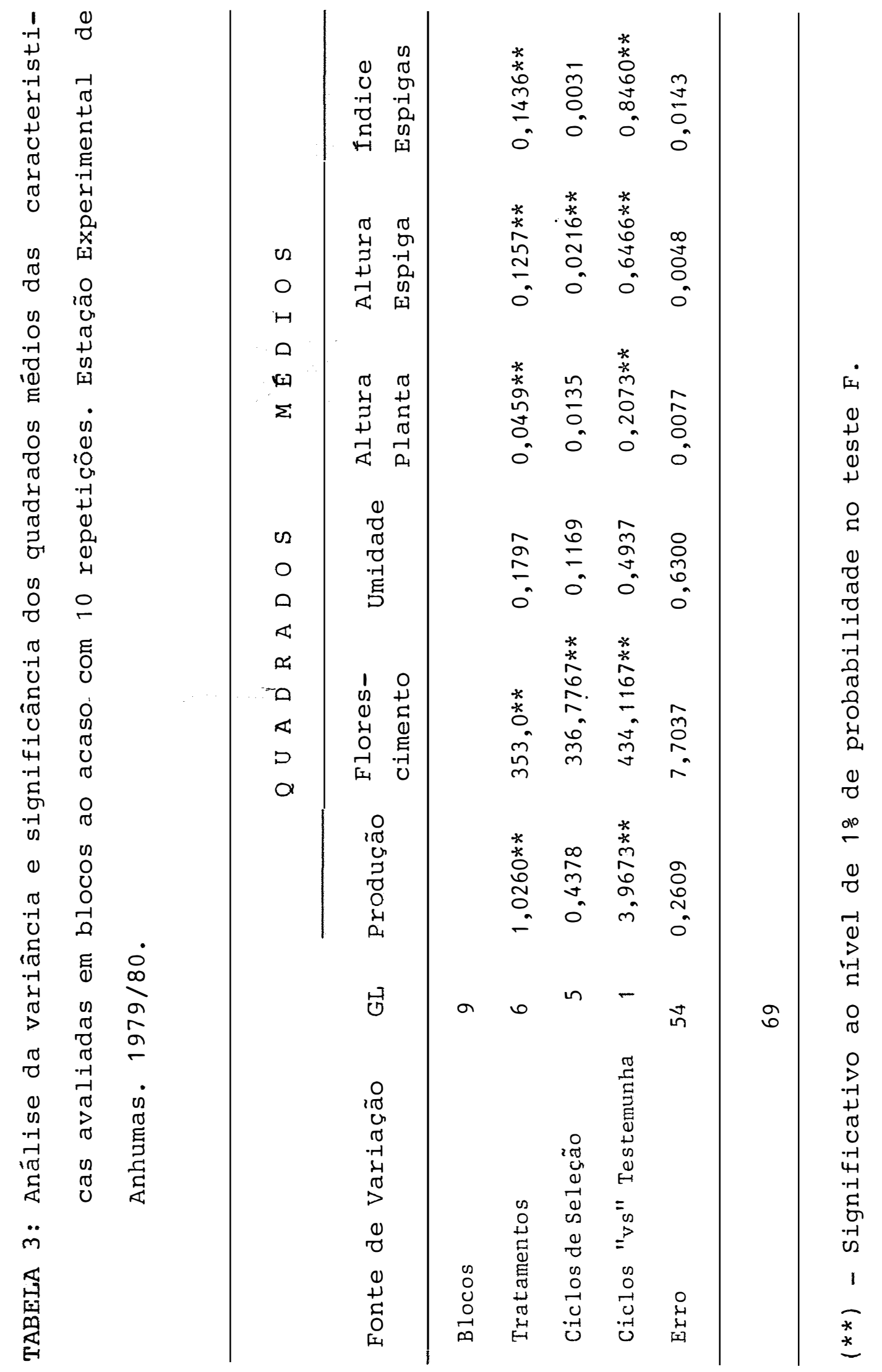




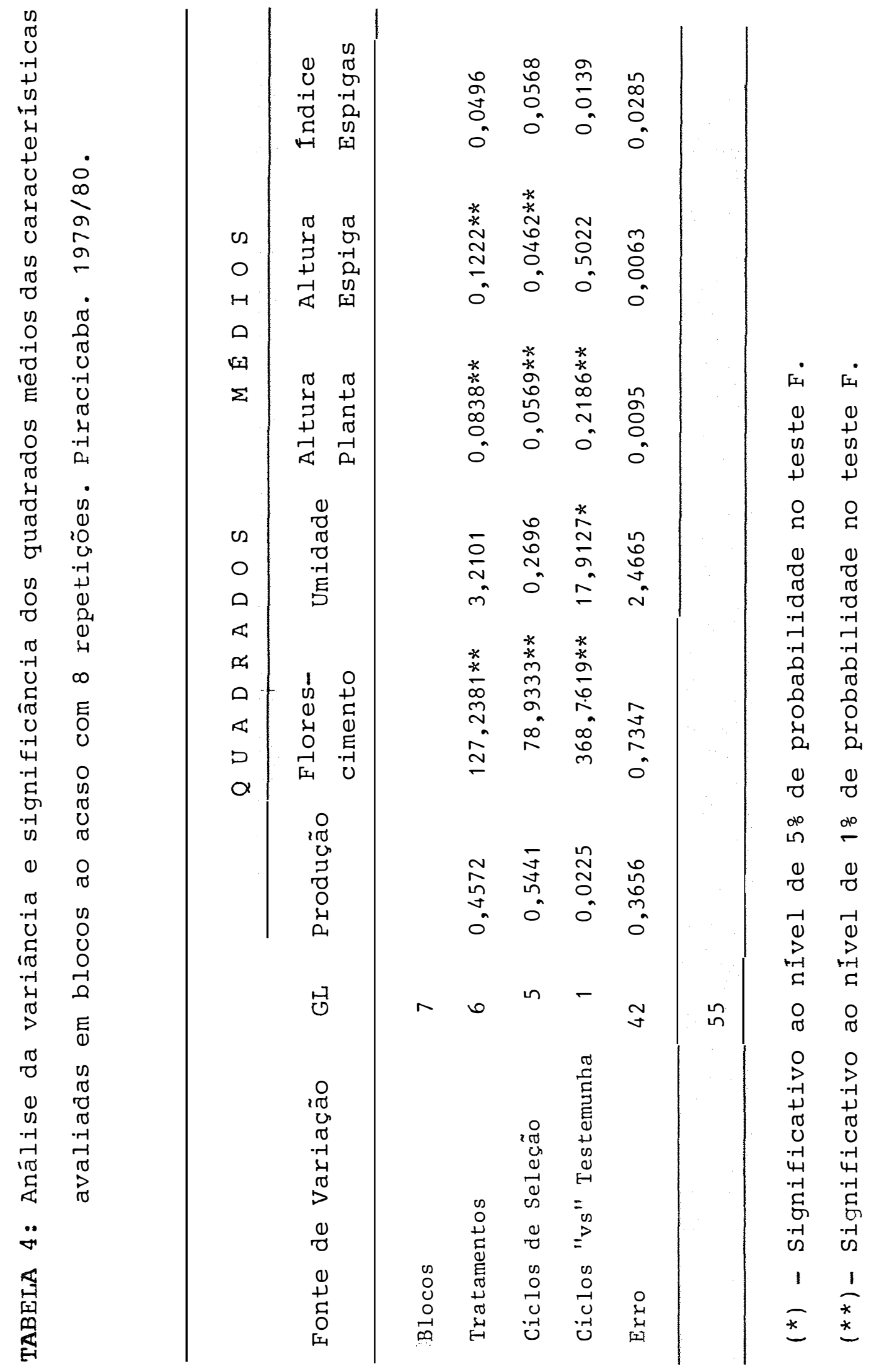




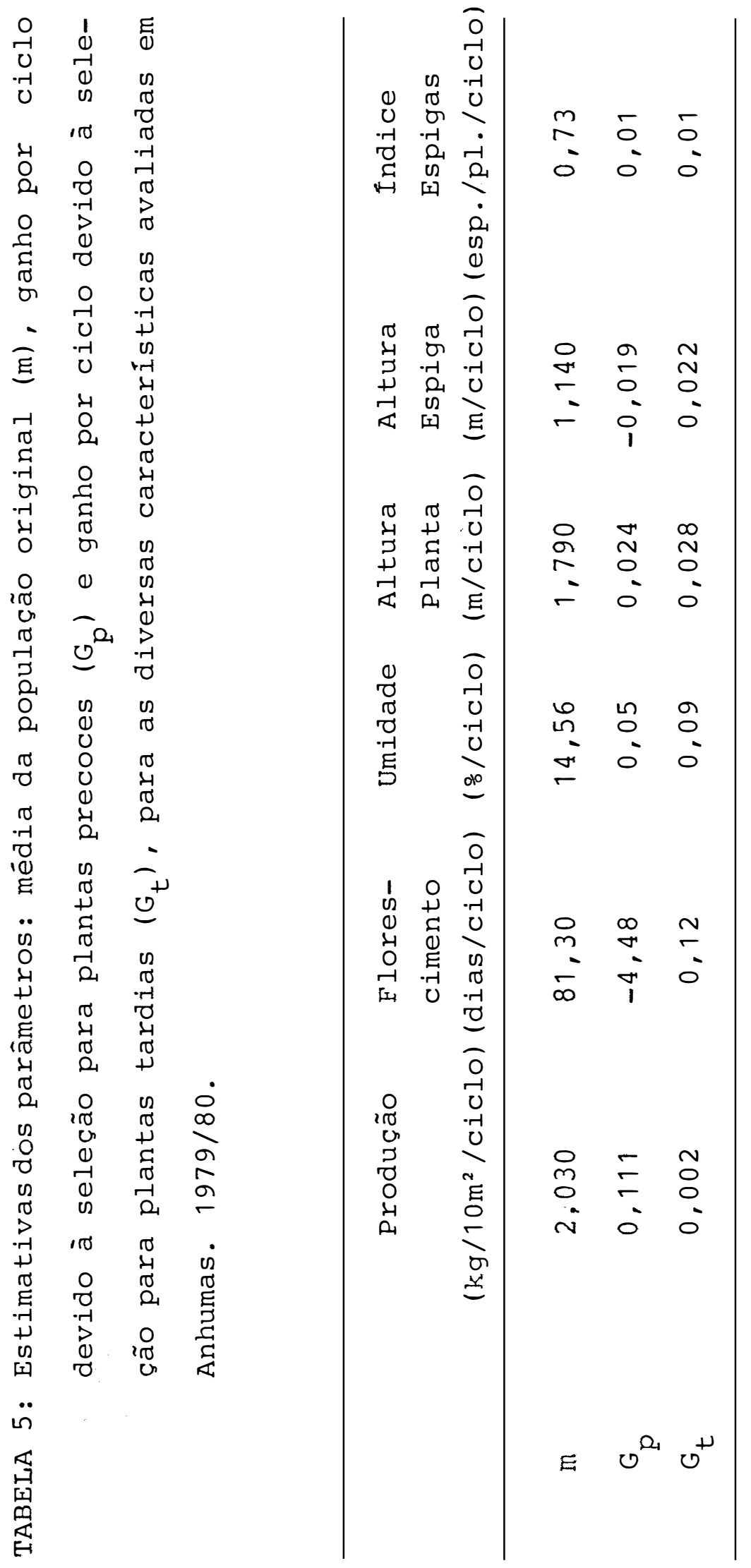




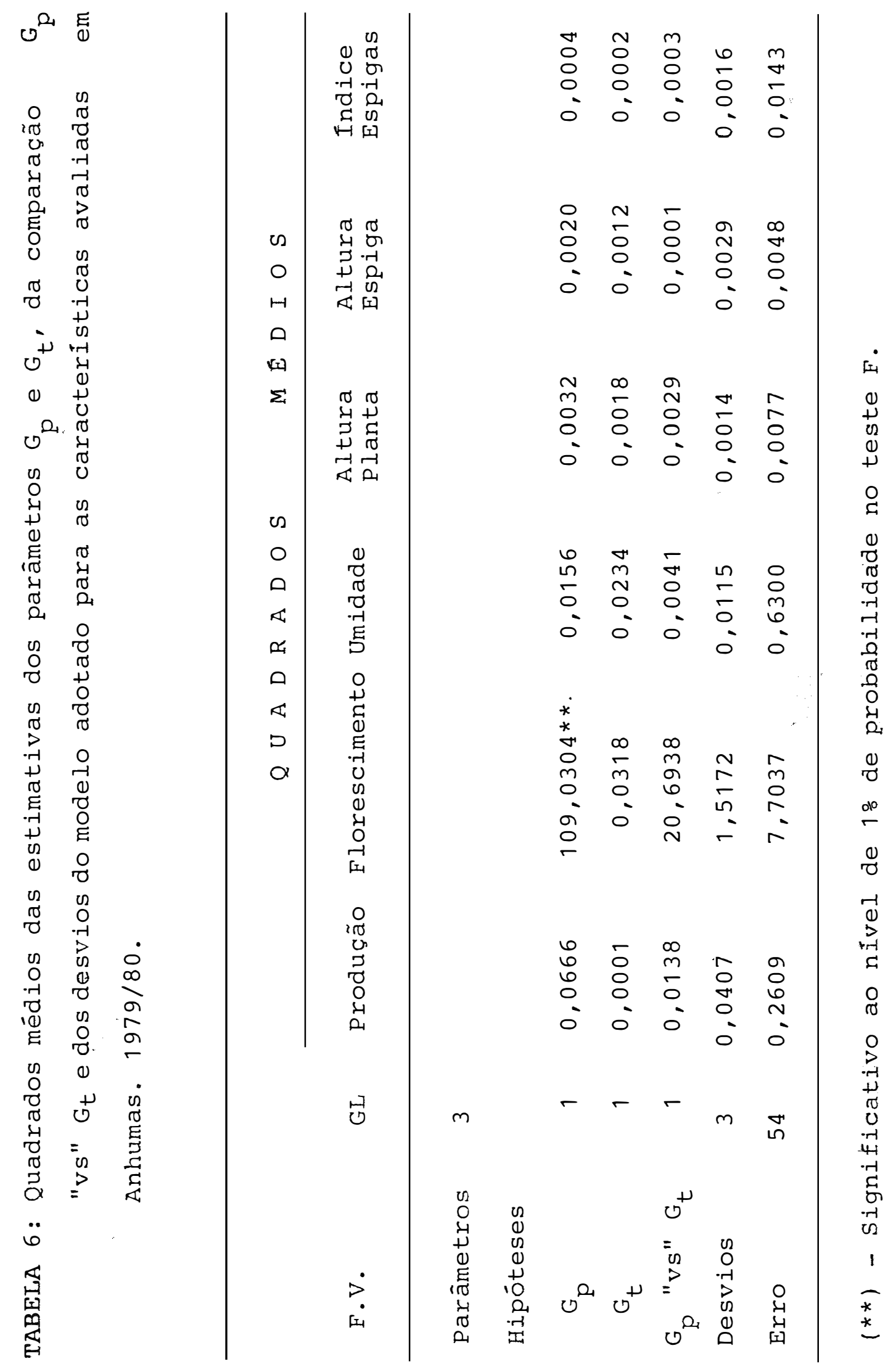




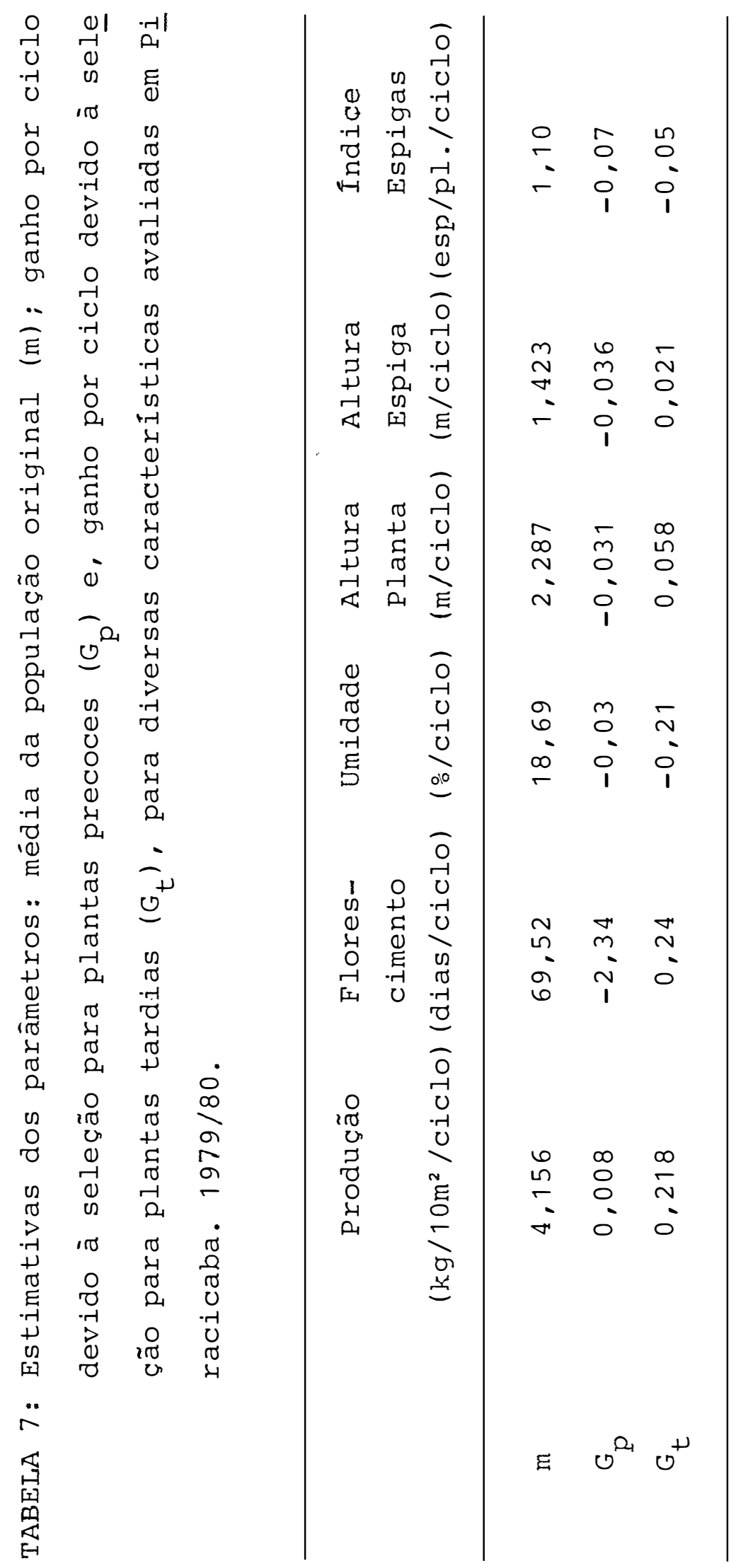




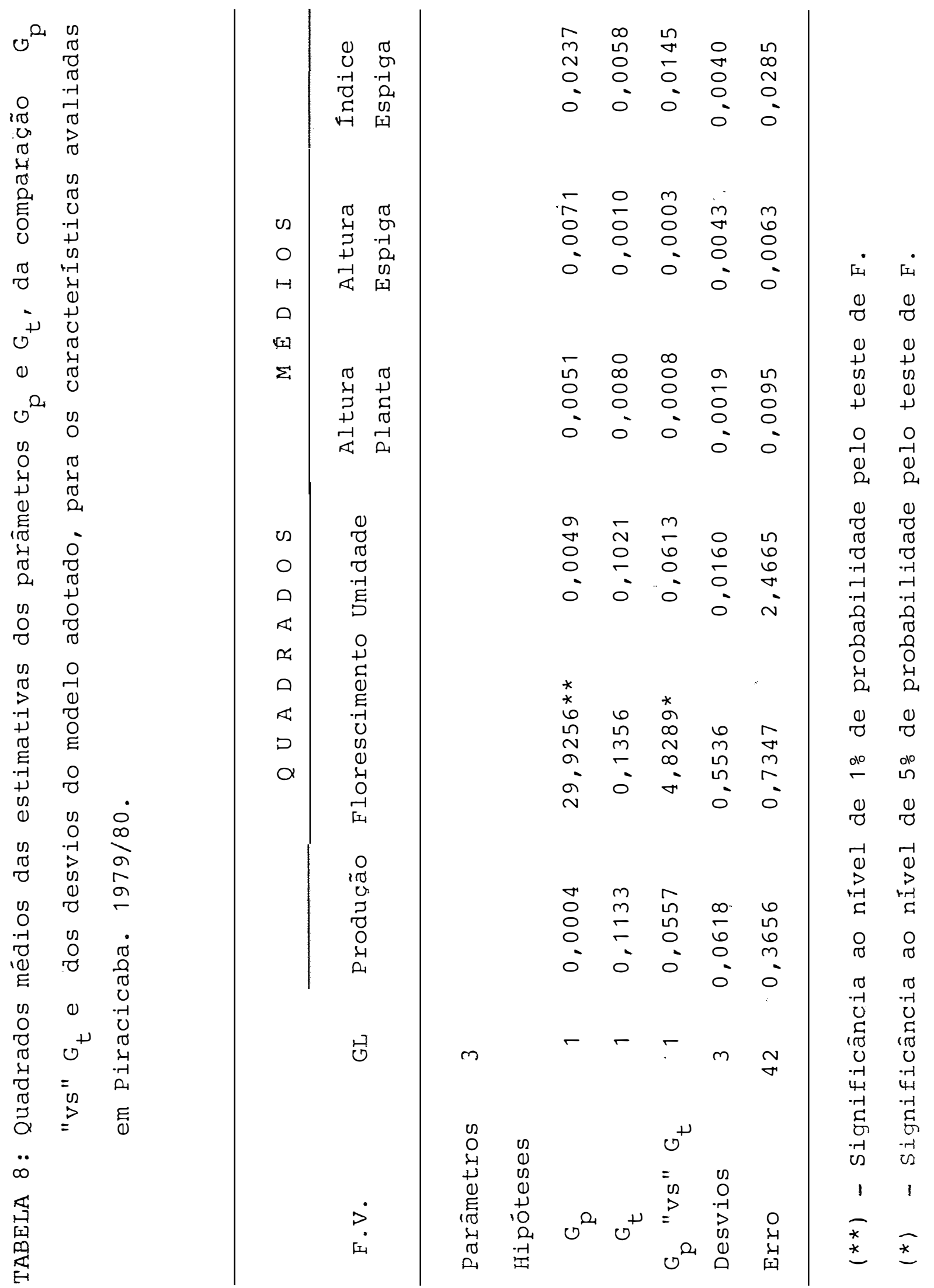




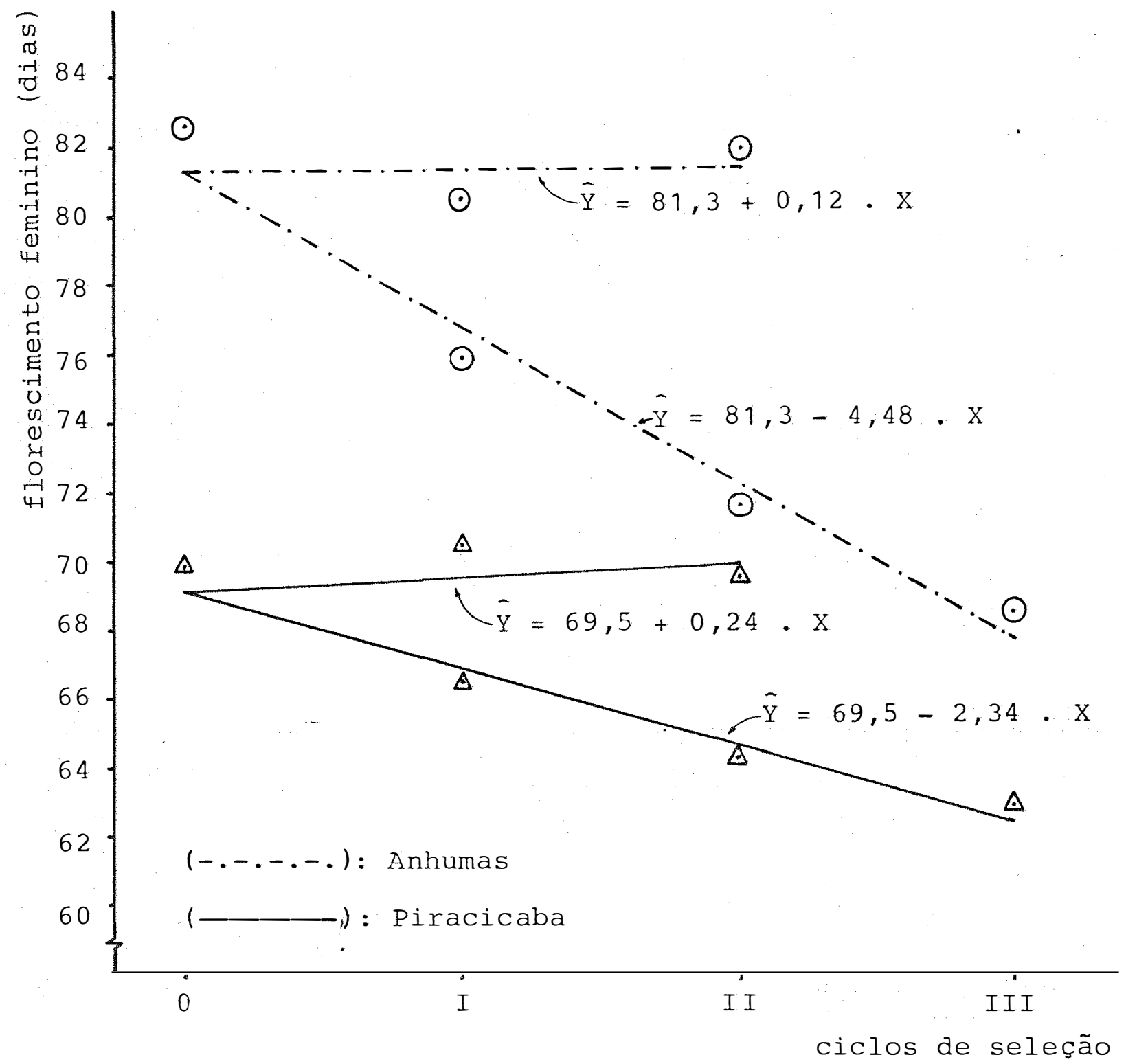

GRÁFICO 1: Regressão linear obtida pelo método dos quadrados minimos, para dias para florescimento feminino sobre ciclos de seleção para precocidade (3) e plantas tardias (2), para cada local avaliado. 